\title{
Pemberdayaan aset daun sirih dan kain bekas dalam meningkatkan pendapatan ekonomi masyarakat Desa Alue Dua di masa pandemi Covid-19
}

\author{
Noratuddini ${ }^{1}$, Rizky Andana Pohan ${ }^{2}$ \\ 1,2 Insitut Agama Islam Negeri Langsa \\ noratuddinisaifuddinali@gmail.com
}

$\begin{array}{ccc}\text { First received: } & \text { Revised: } & \text { Final Accepted: } \\ \text { 01 January } 2021 & \text { 02 February 2021 } & \text { 04 April } 2021\end{array}$

\begin{abstract}
Abstrak
Pandemi Covid-19 telah mempengaruhi dan mengurangi produktivitas masyarakat secara normal, termasuk yang paling terasa oleh masyarakat yaitu aspek ekonomi. Salah satu metode menemukenali aset bersama dengan masyarakat Desa Dua melalui metode Low Hanging Fruit yaitu daun sirih dan kain bekas sebagai kerajinan untuk membantu perekonomian masyarakat. Metode pemberdayaan masyarakat yang digunakan bersama masyarakat berbasis Aset Based Community Development (ABCD). Lokasi Pemberdayaan masyarakat di desa Alue Dua. Lama pelaksanaan pemberdayaan masyarakat selama 45 hari. Langkah-langkah pelaksanaan kegiatan pemberdayaan antara lain: (1) pemetaan aset bersama masyarakat sehingga didapatkan potensi hutan yaitu daun sirih dan potensi kain bekas, (2) pelatihan pembuatan sirih hias, (3) pelatihan pembuatan bros melalui kain bekas, (4) Penjualan melalui media sosial, (5) Membentuk wadah kerajinan masyarakat desa. Pemberdayaan ini menyadarkan masyarakat bahwa daun sirih dan kain bekas yang melimpah dapat menghasilkan sesuatu yang bermanfaat sehingga dapat menambah pendapatan masyarakat, walaupun itu hanya dilakukan di waktu senggang.
\end{abstract}

Kata Kunci: Daun sirih, aset, kain bekas, pandemi Covid-19, ABCD

\begin{abstract}
The Covid-19 pandemic has affected and reduced normal people's productivity, including what is most felt by the community, namely the economic aspect. One method of identifying joint assets with the people of Desa Dua is the Low Hanging Fruit method, namely betel leaves and used cloth as crafts to help the community's economy. The community empowerment method used with the community is based on Asset Based Community Development $(A B C D)$. Locations for community empowerment in Alue Dua village. The duration of the implementation of community empowerment is 45 days. The steps for implementing empowerment activities include: (1) mapping of assets with the community so that forest potential is obtained, namely betel leaf and used cloth potential, (2) training in making ornamental betel, (3) training on making brooches through used cloth, (4) Sales through social media, (5) Forming a village community craft forum. This empowerment makes people aware that the abundance of
\end{abstract}


Pemberdayaanaset daun ... -Noratuddini \& Rizky Andana Pohan

betel leaves and used cloth can produce something useful so that it can increase people's income, even though it is only done in their spare time.

Keywords: Betel leaves, cloth as crafts, assets, the Covid-19 pandemic, ABCD

\section{PENDAHULUAN}

Pengangguran merupakan suatu permasalahan yang belum bisa diatasi di Indonesia sampai saat ini, dan saat ini ditambah lagi dengan adanya COVID-19 yang melanda Indonesia bahkan seluruh negara, sehingga tingkat pengangguran semakin meningkat. Tingkat pengangguran merupakan salah satu masalah yang sangat penting untuk diperhatikan karena tingkat pengangguran sangat berpotensi terjadinya kriminal dikalangan masyarakat karena minimnya penghasilan dikalangan masyarakat. Pemerintah telah melakukan berbagai upaya dalam rangka mengatasi permasalahan tersebut, salah satunya membuka lapangan pekerjaan baru dan di masa pandemi ini pemerintah juga memberikan berbagai bantuan seperti bantuan untuk para UMKM (Kurniawansyah et al., 2020). Namun upaya tersebut belum mampu mengatasi tingkat pengangguran di Indonesia. Tingkat pengangguran juga sangat mempengaruhi kesehatan masyarakat apalagi di masa pandemi COVID-19 seperti ini, jika masyarakat tidak dapat memenuhi kebutuhan gizi yang cukup kesehatan mereka akan terganggu (Arapah, 2020).

Penyebaran COVID-19 yang sangat cepat memang banyak memberi perubahan terhadap kita baik dalam dunia pendidikan, kesehatan maupun bisnis (Sagita \& Hermawan, 2020) . Pada masa pandemi COVID-19 ini banyak bisnis yang menurun drastis atau bahkan tidak memiliki pelanggan sama sekali (Sumarni \& Bengkulu, 2020). Masyarakat juga dianjurkan untuk tetap berada di rumah saja selama masa pandemi COVID-19 ini, meskipun demikian kreativitas juga menjadi sesuatu yang diperlukan untuk memenuhi kebutuhan sehari-hari.

Gampong Alue Dua Paya Gajah adalah sebuah gampong yang berada di Kecamatan Peureulak, Kabupaten Aceh Timur, Provinsi Aceh. Asal mula didirikannya gampong Alue Dua Paya Gajah adalah atas inisiatif beberapa keluarga yang berkeinginan mendirikan sebuah pemukiman, letak pemukiman tersebut terdapat antara Gampong Tualang dan Gampong Paya Kalui, yang kemudian diberi nama Gampong Alue Dua Paya Gajah yang dipimpin oleh seorang Peutua Chik dan Tungku Imum. Asal muasal diberi nama Gampong Alue Dua Paya Gajah adalah diantara 2 titik alur ada kubangan gajah yang terletak di dusun Mampree sekarang. Luas Gampong Alue Dua Paya Gajah 2.1 km2 dengan jumlah penduduk 762 jiwa/ 165 KK. Gampong Alue Dua Paya Gajah memiliki jarak dari pusat kecamatan sejauh $8 \mathrm{~km}$, jarak dari pusat kabupaten sejauh 30 km, serta jarak dari pusat provinsi sejauh $399 \mathrm{~km}$. Gampong Alue Dua Paya Gajah merupakan daerah yang bersifat agraris, dengan mayoritas penduduknya bermata pencaharian petani dan pekebun. Sebagian kecil juga ada yang menjadi pedagang maupun beternak. Potensi sumber daya alam yang terdapat di Gampong Alue Dua Paya Gajah ialah tersedianya lahan pertanian, perkebunan, hutan dan ladang tempat memelihara ternak yang terletak di semua dusun. Untuk situasi seperti ini kita bisa menggunakan bahan-bahan yang mudah didapatkan dan menghemat pengeluaran. Salah satu potensi yang banyak di desa ini ialah daun sirih dan kain bekas yang berasal dari 
kebun dan sisa menjahit dan pakaian yang tidak terpakai lagi. Seperti pembuatan pengait masker kita bisa membuatnya dari kain perca, begitu juga bros. Sedangkan untuk sirihnya kita bisa mendapatkannya dari sumber daya alam yang tersedia di sekitar kita. Hasil kreativitas tersebut dapat dipromosikan melalui media sosial seperti WhatsApp, Instagram dan Facebook. Hasil penjualan tersebut dapat dimanfaatkan untuk memenuhi kebutuhan perekonomian masyarakat dalam memenuhi kebutuhan sehari-hari kita agar tercukupinya keseimbangan gizi yang baik.

Hal inilah juga yang mendasari pengabdi untuk bersama-sama masyarakat memberdayakan aset daun sirih dan kain bekas yang selama ini belum dimaksimalkan oleh masyarakat. Lahan yang sempit tetapi jika dimanfaatkan secara maksimal juga akan menghasilkan sesuatu yang bermanfaat terutama untuk menunjang aspek ekonomi masyarakat Desa Alue Dua selama pandemi Covid-19. Berdasarkan analisis kebutuhan dan pemetaan aset yang dilakukan bersama warga maka disepakati sebuah program pemberdayaan masyarakat dengan pemanfaatan lahan kosong untuk dikelola sebagai lahan pertanian yang dapat bermanfaat untuk masyarakat (Pohan \& Siregar, 2020).

\section{METODE}

Pelaksanaan pemberdayaan masyarakat dilaksanakan di Desa Alue Pineung Kota Langsa selama 45 hari. Subjek pengabdian merupakan seluruh warga masyarakat yang memiliki potensi pekarangan rumah yang belum ter manfaatkan dengan baik. Metode pengabdian yang digunakan berbasis potensi ataupun aset masyarakat yaitu ABCD (Asset Based Community Development yang ditemukan yaitu daun sirih dan kain bekas (Ennis \& West, 2010). Analisis keberhasilan diketahui melalui kegiatan monitoring dan evaluasi yang meliputi: perubahan yang signifikan, alur sejarah, alur sirkulasi keuangan, pemetaan fisik, serta pemetaan institusi (Mathie \& Cunningham, 2003)

\section{HASIL DAN PEMBAHASAN}

Program pemberdayaan masyarakat dilaksanakan selama \pm 45 hari terhitung sejak tanggal 1 Desember 2020 sampai 14 Januari 2021. Langkah-langkah pelaksanaan kegiatan pemberdayaan antara lain: (1) pemetaan aset bersama masyarkat sehingga didapatkan potensi hutan yaitu daun sirih dan potensi kain bekas, (2) pelatihan pembuatan sirih hias, (3) pelatihan pembuatan bros melalui kain bekas, (4) Penjualan melalui media sosial, (5) Membentuk wadah kerajinan masyarakat desa. Hasil dari pemberdayaan ini terlihat bahwa sebelum dan sesudah dilaksanakan masyarkat mulai memahami dari kreativitas membuat kerajinan sirih dan bros serta pengait masker dari kain bekas dapat membantu perekonomian masyarakat apalagi dengan membentuk wadah kerajinan masyarakat. Secara signifikan seluruh masyarakat mulai tersadar dan bersemangat untuk memanfaatkan waktu senggang untuk membuat dan memasarkan kerajinan daun sirih, bros, dan pengait masker. Berikut ini gambar alur pelaksanaan pemberdayaan masyarakat yang telah dilaksanakan 


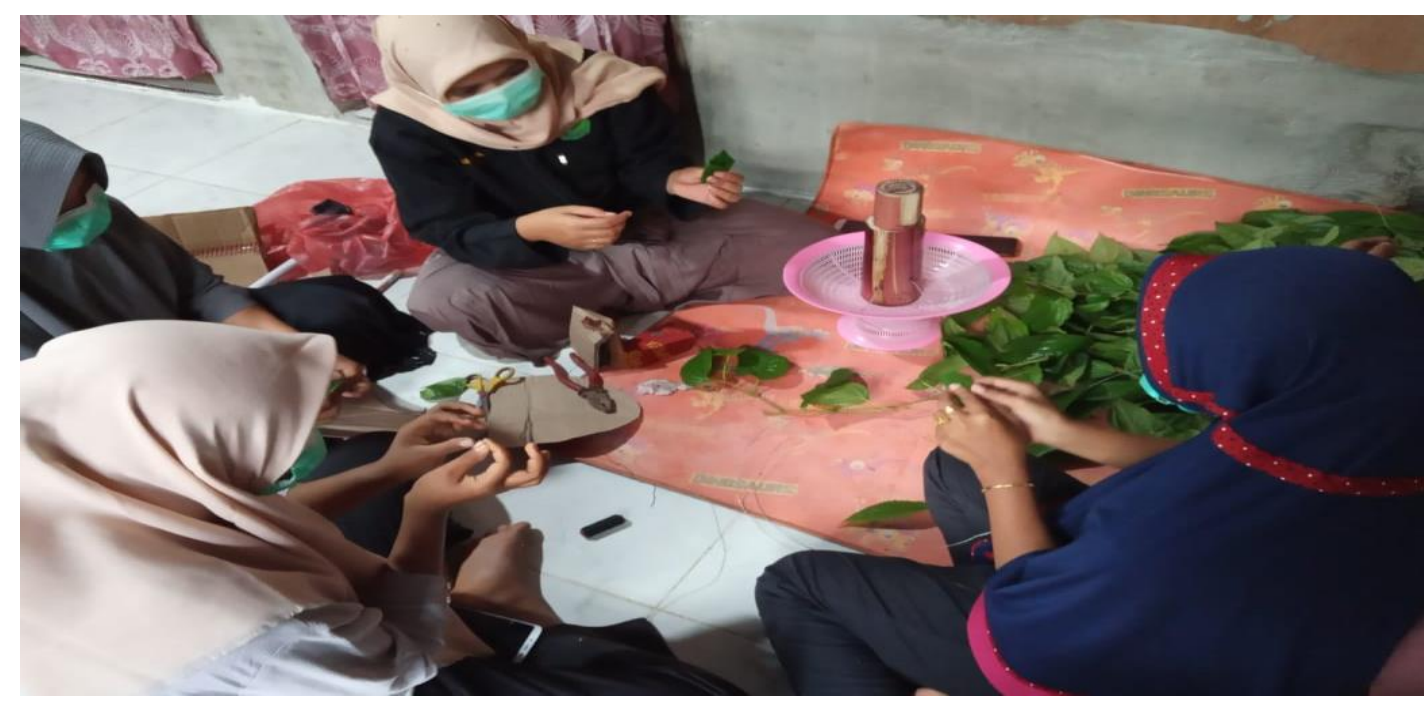

Gambar 1. Pemetaan Aset bersama masyarakat
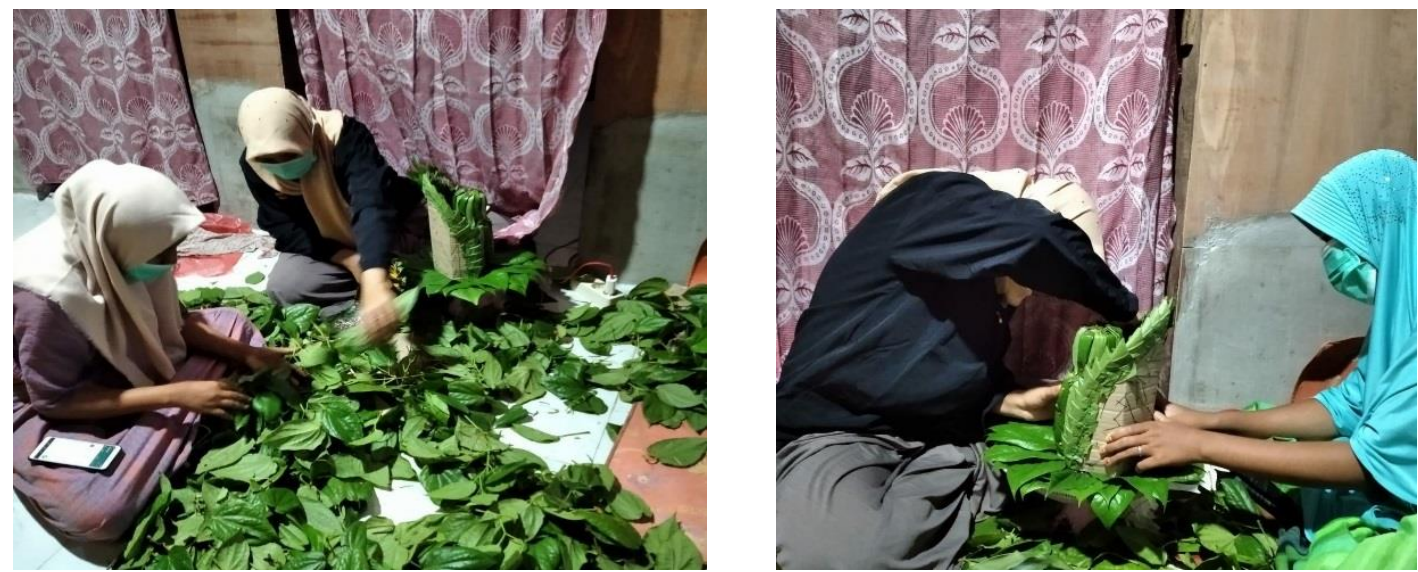

Gambar 2. Pelatihan membuat kerajinan daun sirih

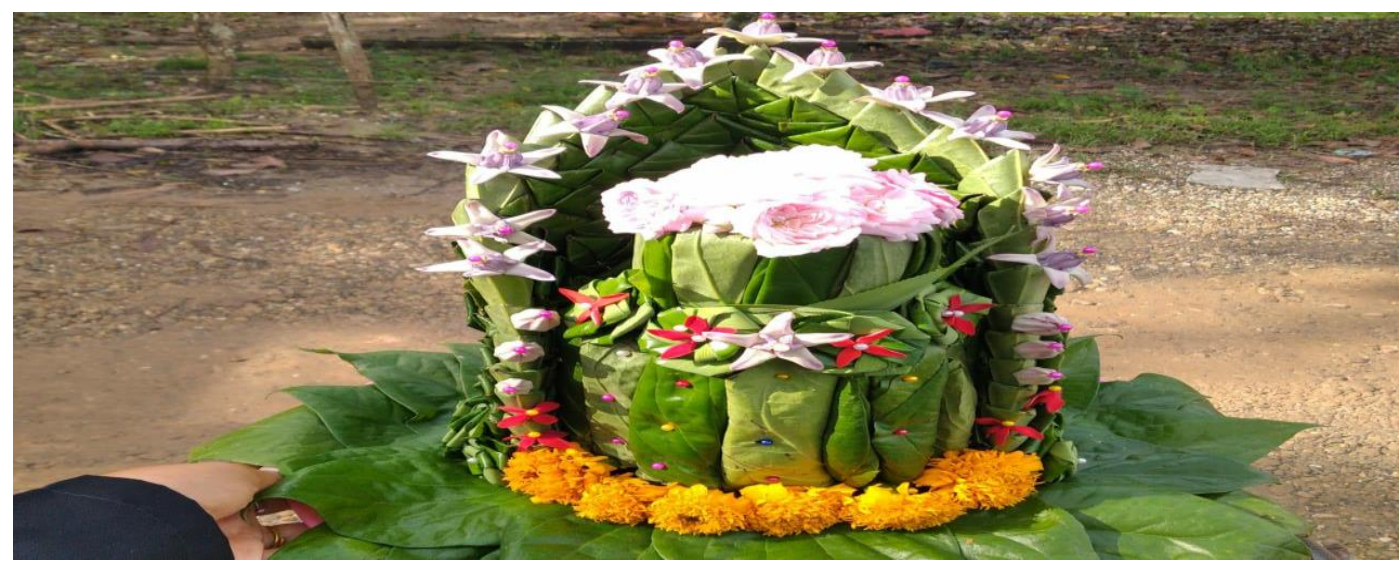

Gambar 3. Hasil kerajinan daun sirih yang siap dipasarkan 

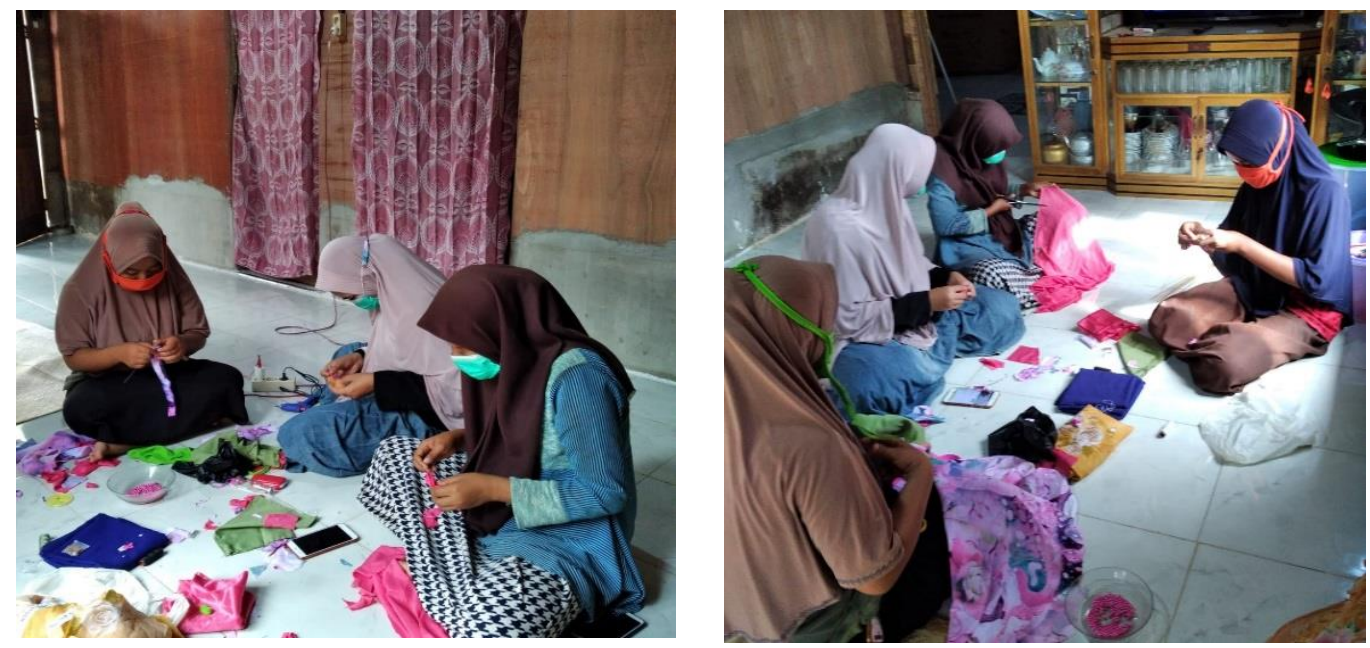

Gambar 4. Pelatihan membuat bros dan pengait masker
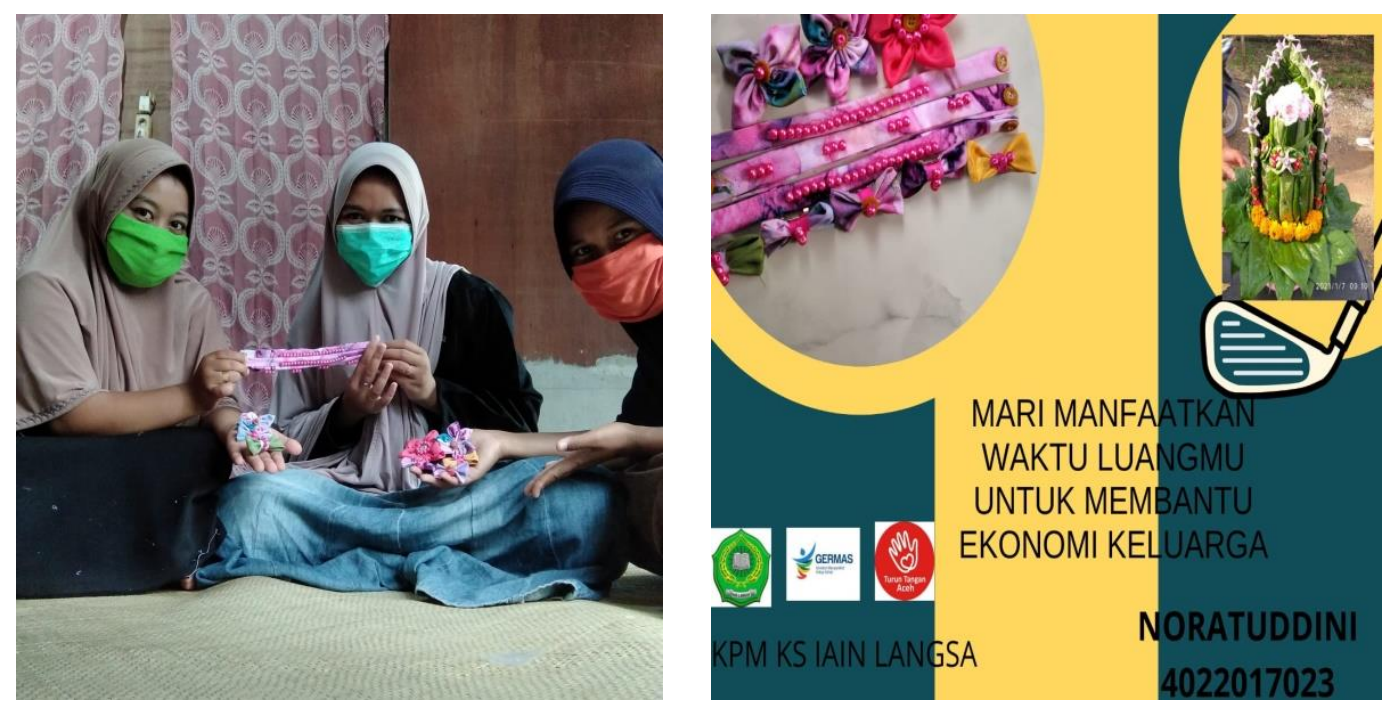

Gambar 5. Hasil bros dan pengait masker dan Promosi melalui media sosial

\section{Pemanfaatan Daun Sirih dan Kain Bekas untuk Menambah Penghasilan Masyarakat}

Pemberdayaan yang dilakukan bersama masyarkat berbasis aset, sehingga langkah pertama yang dilakukan adalah pemetaan aset bersama. Setelah dianalisis ternyata bersama masyarakat ditemukan daun sirih yang jumlahnya banyak serta memanfaatkan kain bekas untuk lebih bermanfaat. Hal inilah yang kemudian yang menjadi fokus pemberdayaan. Waktu senggang yang tersisa dimanfaatkan untuk membuat kerajinan daun sirih dan bros serta pengait masker bersama masyarakat melalui wadah dewan kerajinan desa. Proses selanjutnya yang penting adalah melibatkan para remaja untuk menyosialisasikan penjualan hasil kerajinan melalui media sosial masingmasing sehingga dapat diketahui oleh seluruh lapisan masyarakat yang tidak terbatas ruang dan waktu. Karena remaja merupakan aset yang berguna untuk memainkan peran di media sosial secara aktif (E.B. \& S.W., 2017) meskipun mereka dapat juga menyalahgunakan media sosial yang digunakan melalui smartphone tetapi di sinilah peran wadah kerajinan yang dapat memberdayakan semua potensi (Prihatin Nufus et al., 2020). Kebersamaan pemberdayaan ini terus berlanjut secara mandiri dengan 
terbentuknya dewan kerajinan desa. Seluruh masyarakat bersinergi untuk memanfaatkan daun sirih dan kain bekas yang ada di lingkungan masing-masing melalui wadah kerajinan desa. Antusiasme dan respon masyarakat sangat baik karena memang pemetaan aset yang dilakukan secara bersama-sama dengan melibatkan banyak pihak, dengan tetap memperhatikan respon dari pihak-pihak terkait baik pertanyaan, sanggahan, masukan dari masyarakat dipengaruhi oleh konsep diri mereka yang baik untuk terus membuat dan menghasilkan inovasi lainnya (Pohan et al., 2018). Selanjutnya untuk menghasilkan inovasi yang beragam diperlukan membaca berbagai literatur terkait pemanfaatan daun sirih dan kain bekas dalam menambah keterampilan (Marimbun, 2019). Keberhasilan pemberdayaan ini tidak terlepas dari strategi pemberdayaan ABCD yaitu memanfaatkan potensi terdekat terlihat dahulu, baru kemudian menemukan aset yang lebih besar untuk tujuan bersama (Nel, 2015).

\section{KESIMPULAN}

Program pengabdian masyarakat berbasis ABCD ini terbukti berhasil meningkatkan kesadaran masyarakat untuk memanfaatkan sesuatu hal yang selama ini terbengkalai yaitu daun sirih dan kain bekas namun ternyata dapat dimanfaatkan untuk menambah ketahanan pangan dan ekonomi keluarga selama maupun pasca pandemi Covid-19. Program ini berhasil dikarenakan pemetaan aset yang dilakukan secara bersama-sama dengan masyarakat berdasarkan atas potensi-potensi yang paling dekat dimiliki.

\section{UCAPAN TERIMAKASIH}

Kami mengucapkan terimakasih kepada LP2M IAIN Langsa yang telah mendukung program pengabdian ini serta kepada seluruh kelompok ibu-ibu Desa Alue Dua yang telah berperan aktif dalam pelaksanaan program dan juga semua rekan-rekan yang telah membantu kelangsungan program pemberdayaan masyarakat.

\section{DAFTAR PUSTAKA}

Arapah, N. (2020). Analisis Pengaruh Bantuan Sosial PKH Dan Sembako Terhadap Tingkat Kesejahteraan Masyarakat Ditengah Pandemic Covid 19 Di Kabupaten Barito Utara. JURNAL ILMU EKONOMI (MANAJEMEN PERUSAHAAN) DAN BISNIS, 4(02), 57-65. https://doi.org/10.51512/jimb.v4i02.58

E.B., G. A., \& S.W., E. D. (2017). Hubungan Penggunaan Media Sosial dengan Tingkat Kepekaan Sosial di Usia Remaja. Jurnal The Messenger, 9(1), 65. https://doi.org/10.26623/themessenger.v9i1.428

Ennis, G., \& West, D. (2010). Exploring the potential of social network analysis in assetbased community development practice and research. Australian Social Work, 63(4), 404-417. https://doi.org/10.1080/0312407X.2010.508167

Kurniawansyah, H., Amrullah, M., \& Salahuddin, N. (2020). KONSEP KEBIJAKAN 
STRATEGIS DALAM MENANGANI EKSTERNALITAS EKONOMI DARI COVID19 PADA MASYARAKAT RENTAN DI INDONESIA. In Indonesian Journal of Social Sciences and Humanities (Vol. 1, Issue 2).

Marimbun, M. (2019). Minat Membaca dan Implementasinya dalam Bimbingan dan Konseling. ENLIGHTEN: Jurnal Bimbingan Konseling Islam, 2(2), 74-84. https://doi.org/10.32505/ENLIGHTEN.V2I2.1361

Mathie, A., \& Cunningham, G. (2003). From clients to citizens: Asset-based Community Development as a strategy for community-driven development. Development in Practice, 13(5), 474-486. https://doi.org/10.1080/0961452032000125857

Nel, H. (2015). An integration of the livelihoods and asset-based community development approaches: A South African case study. Development Southern Africa, 32(4), 511-525. https://doi.org/10.1080/0376835X.2015.1039706

Pohan, R. A., Hayati, R. H., \& Sahputra, D. S. (2018). KONTRIBUSI MOTIVASI BERPRESTASI DAN KONSEP DIRI TERHADAP KEGIATAN MERESPON DALAM PEMBELAJARAN SERTA IMPLIKASINYA DALAM BIMBINGAN DAN KONSELING. Wahana Didaktika : Jurnal Ilmu Kependidikan, 16(2), 145. https://doi.org/10.31851/wahanadidaktika.v16i2.1941

Pohan, R. A., \& Siregar, M. (2020). Need Assesment of Guidance and Counseling Module to Improve Freshmen Self-Adjustment. Biblio Couns : Jurnal Kajian Konseling Dan Pendidikan, 3(3), 113-119. https://doi.org/10.30596/BIBLIOCOUNS.V3I3.5221

Prihatin Nufus, N., Fitri, S., \& Wirasti, M. K. (2020). Penggunaan Smartphone Bermasalah Pada Siswa SMA Serta Implikasinya Bagi Pelayanan Bimbingan dan Konseling di Sekolah. ENLIGHTEN (Jurnal Bimbingan Dan Konseling Islam), 3(2), 96-105. https://doi.org/10.32505/enlighten.v3i2.1941

Sagita, D. D., \& Hermawan, D. (2020). Kesepian Remaja Pada Masa Pandemi COVID-19. ENLIGHTEN (Jurnal Bimbingan Dan Konseling Islam), 3(2), 122-130. https://doi.org/10.32505/enlighten.v3i2.1892

Sumarni, Y., \& Bengkulu, I. (2020). PANDEMI COVID-19: TANTANGAN EKONOMI DAN BISNIS. In Al-Intaj : Jurnal Ekonomi dan Perbankan Syariah (Vol. 6, Issue 2). https://doi.org/10.29300/AIJ.V6I2.3358 